\title{
混合粒径土砂の盛土養浜時の広がり予測
}

\section{Prediction of Nourishment Material Composed of Mixed Grain Size in Foreshore Nourishment}

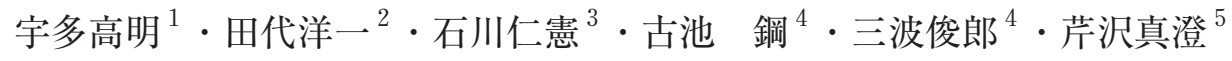 \\ Takaaki UDA, Yoichi TASHIRO, Toshinori ISHIKAWA, Kou FURUIKE \\ Toshiro SAN-NAMI and Masumi SERIZAWA
}

\begin{abstract}
On the Hamamatsu-shinohara coast facing the Pacific Ocean, beach has been severely eroded, resulting in the shoreline recession of $210 \mathrm{~m}$ between 1962 and 2004. As a measure against beach erosion, beach nourishment using the mixture of sand and gravel was begun in 2005 . Since then, $3.5 \times 10^{5} \mathrm{~m}^{3}$ of sediment was supplied to the coast. In this study, we proposed a model for predicting the movement of gravel by waves. The predicted and measured results were in good agreement.
\end{abstract}

\section{1. まえがき}

遠州灘海岸では, 天竜川からの流出土砂量の激減に伴 い河口両翼の海岸で侵食が進み, 河口の西 $4 \mathrm{~km}$ に位置す る浜松篠原海岸では1962年から2004年までに汀線が最 大 $210 \mathrm{~m}$ 後退した（長島ら, 2005)。この対策として, 離 岸堤 3 基と $5 \times 10^{4} \mathrm{~m}^{3} / \mathrm{yr}$ の維持養浜による保全対策が提案 され（宇多ら，2006），計画は実施に移されてきた。本来 細砂中砂で構成されている遠州灘海岸においては, 海浜 の質的 (粒径) 変化を防止する上では細砂中砂による養 浜が必要であるが，一方で養浜により効果的な海岸保全 を図るには粗粒材の投入も有効と考えられる（宇多ら， 2007). 現実には両者のバランスを取ることが求められ るが，実際に現地海岸では2009年までに計 $3.5 \times 10^{5} \mathrm{~m}^{3}$ の 鿬を多く含む粗粒材養浜が行われた。この結果養浜によ る海岸保全効果が現れつつあるが，同時に海浜の質的変 化が生じている．前述したように，海浜の質的変化を防 止する観点からは，その海岸にあるのと同様な粒径特性 を持つ土砂により養浜を行うことが望ましい. しかし材 料の調達上礫材が混じる場合もあり，また浜松篠原海岸 のように防護機能の早期発現を図るために汀線付近に歩 留る相対的に粗な粒径の土砂を用いなければならない場 合もある.そこで本研究では浜松篠原海岸で行われた粗 粒材養浜による海浜変形の実態データを検証材料とし て, 熊田ら（2003）の粒径を考慮した等深線変化モデル を用いて砂の移動状況の再現計算を行った。

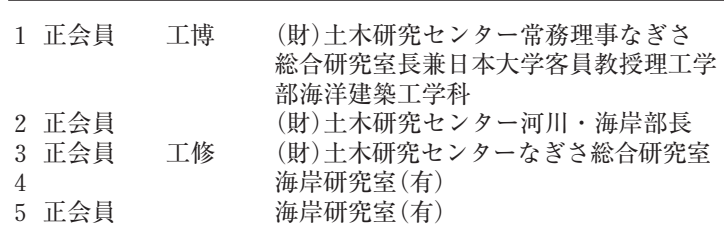

\section{2. 粗粒材養浜に伴う海浜変形}

浜松篠原海岸における粗粒材養浜前の 2005 年と, 養浜 後の 2009年の空中写真を図-1に示す．養浜は馬込川河口 西側の長さ $400 \mathrm{~m}$ 区間で比高 $7 \mathrm{~m}$ の盛土形状で行われ, 2005 年 1 月より 2009 年 6 月までに合計 $3.5 \times 10^{5} \mathrm{~m}^{3}$ の養浜 材が投入された（静岡県, 2009).またこの間に馬込川河 口の西 $1.6 \mathrm{~km}$ には堤長 $100 \mathrm{~m}$ の離岸堤も設置された. 比高 $7 \mathrm{~m}$ で汀線付近に盛土された礫を含む養浜土砂は, 波の作 用により盛土斜面の基部から土砂が運び去られると上部 の土砂が崩落し, 再び波の作用で削り取られるという過 程を経て, 養浜土砂は次第に養浜区域から西向きに運ば れた。養浜は天端高 T.P. $+7 \mathrm{~m}$ の盛土状に行われたため, 全量が海へ供給された訳ではないが，図-1に示すように 2005 年と養浜後の 2009 年 1 月の汀線形状を比較すれば, 馬込川河口から砂丘前面にかけて海浜が大きく広がった ことが分かる。養浜が開始された 2005 年 1 月から 2009年 9月16日までの竜洋波浪観測所における有義波高と周期 の観測によると, 期間中のエネルギー平均波は $H=1.2 \mathrm{~m}$,

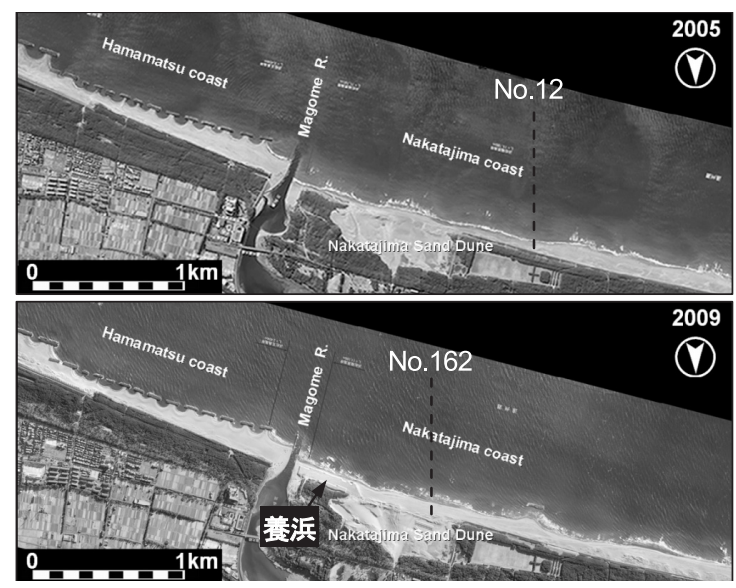

図-1 粗粒材養浜前後の空中写真（静岡県撮影） 


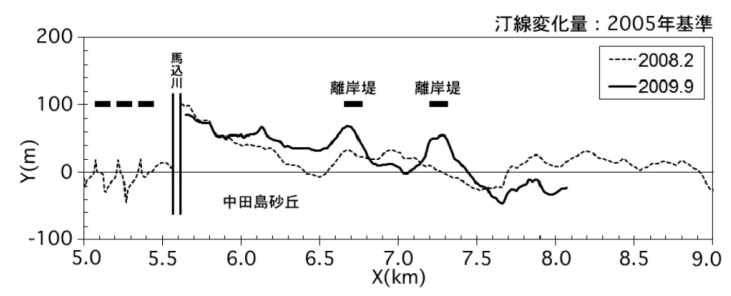

図-2 2005年基準とする 2009年9月までの汀線変化

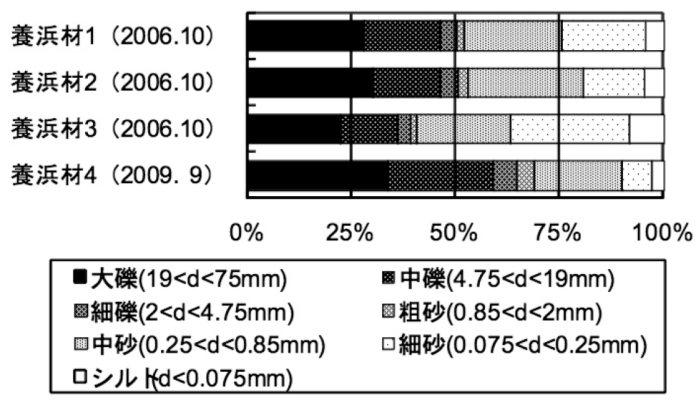

養浜材 $1,2,3$ のデータ:静岡県

図-3 養浜材の粒度組成
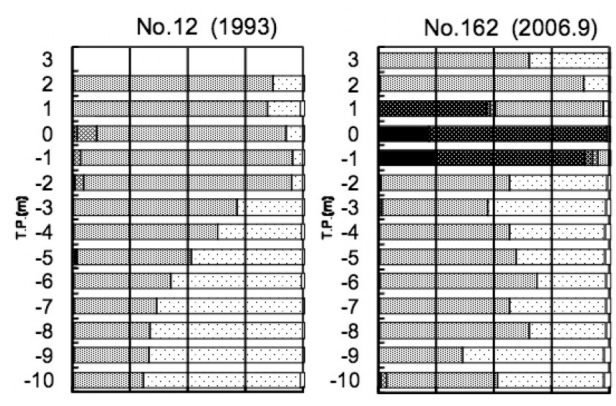

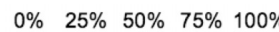

\begin{tabular}{|c|c|}
\hline - 大磎 $(19<\mathrm{d}<75 \mathrm{~mm})$ & 僉中磷( $(4.75<\mathrm{d}<19 \mathrm{~mm}$ ) \\
\hline 固細磁( $(2<\mathrm{d}<4.75 \mathrm{~mm})$ & 圆粗砂 $(0.85<\mathrm{d}<2 \mathrm{~mm})$ \\
\hline $\begin{array}{l}\text { घ中砂 }(0.25<\mathrm{d}<0.85 \mathrm{~mm}) \\
\text { ロシル } 1(\mathrm{~d}<0.075 \mathrm{~mm})\end{array}$ & 区細砂 $(0.075<\mathrm{d}<0.25 \mathrm{~mm})$ \\
\hline
\end{tabular}

データ: 静岡県

図-4 養浜前後の底質の水深方向分布の比較（静岡県）

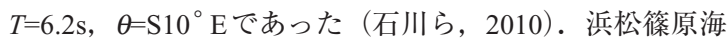
岸では, 海岸線に立てた法線の方向は $\mathrm{S} 16^{\circ} \mathrm{W}$ なので, $26^{\circ}$ 東寄りからの入射となり, 西向きの沿岸漂砂が卓越 する条件であった。

図-2には2005年を基準とした 2009年9月までの汀線変 化を，この間に整備された 2 基の離岸堤の位置とともに 示す。な脑図-1では離岸堤は1基のみ示されているが, 残りの 1 基は空中写真撮影の行われた 2009 年 1 月から 9 月 までの間に設置された．養浜と離岸堤の建設により，養 浜筒所前面や離岸堤背後では $30 \mathrm{~m}$ 程度汀線が前進したこ とが分かる。このように汀線は前進したものの, 同時に
表-1 計算条件

\begin{tabular}{|c|c|}
\hline 計算モデル & $\begin{array}{l}\text { 粒径を考慮した等深線変化モデル（熊田ら,2003） } \\
\text { 回折計算：不規則波の方向分散法（酒井ら, 2003） }\end{array}$ \\
\hline 計算対象区域 & 天竜川河口から西30km地点まで \\
\hline 計算ケース & $\begin{array}{l}\text { 1. 2005年再現（養浜前） } \\
\text { 2. 2008年再現（離岸堤設置直前） } \\
\text { 3. 2009年再現（現在） } \\
\text { 4. 放置10年後 }\end{array}$ \\
\hline 初期地形 & 直線平行等深線 \\
\hline 入射波条件 & $\begin{array}{l}\text { 沖波波高 } \mathrm{H}=1.6 \mathrm{~m}, \text { 周期 } \mathrm{T}=7 \mathrm{~s} \text { (エネルギー平均波) } \\
\text { 波向 }: \mathrm{S} 1962 \text { 年初期汀線への波の入射角 } \\
\theta_{w}=20^{\circ}, S_{\max }=10 \\
\text { 波高の低減率の最小しきい值 } 0.4 \\
\text { 波の抽出回数 } 1 \text { step毎 }\end{array}$ \\
\hline 潮位条件 & M.S.L. $=$ T.P. $\pm 0.0 \mathrm{~m}$ \\
\hline 計算等樑線 & $\mathrm{z}=+3 \mathrm{~m} \sim-9 \mathrm{~m} \quad h_{C}=9 \mathrm{~m} \quad$ バーム高 $h_{R}=3 \mathrm{~m}$ \\
\hline $\begin{array}{l}\text { 計算空間 } \\
\text { メッシュ }\end{array}$ & 沿岸方向 $\Delta X=100 \mathrm{~m}$, 鉛直方向 $\Delta Z=1 \mathrm{~m}$ \\
\hline $\begin{array}{l}\text { 計算時間間隔 } \\
\Delta t\end{array}$ & $\Delta t=50 \mathrm{hr}$ \\
\hline $\begin{array}{l}\text { 計算ステップ } \\
\text { 数 }\end{array}$ & 175.2ステップ／yr \\
\hline 粒径 & 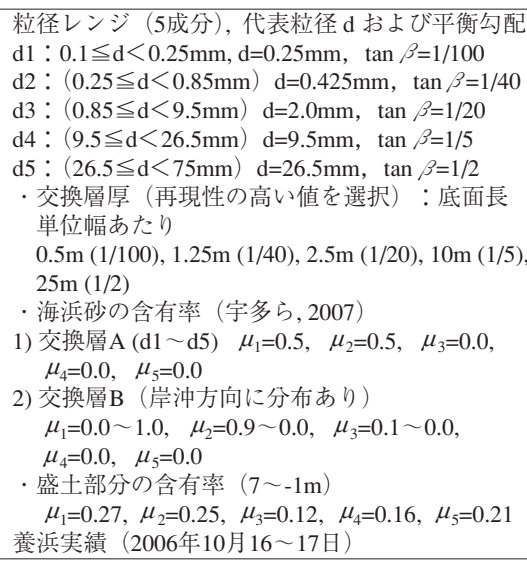 \\
\hline 漂砂量 & 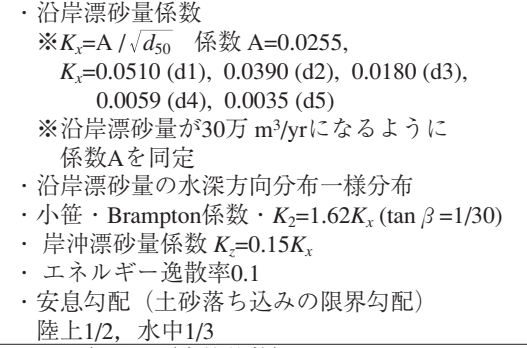 \\
\hline 境界条件 & $\begin{array}{l}\cdot 1962 \text { 年再現（自然状態） } \\
\text { 河口・右端では汀線固定（漂砂の流入出自由） } \\
\text { 岸沖端： } q_{z}=0 \text { (漂砂の流入出なL) } \\
\cdot 2005 \text { 年再現, } 2008 \text { 年再現, } 2009 \text { 年再現, } \\
\text { 将来予測 } \\
\text { 河口 } q_{i n}=0 \mathrm{~m}^{3} / \mathrm{yr} \\
\text { 右端 } q_{o u t}=\text { 汀線固定（漂砂の流入出自由） } \\
\text { 岸沖端 }: q_{z}=0 \text { (漂砂の流入出なし) }\end{array}$ \\
\hline $\begin{array}{l}\text { 盛土養浜の } \\
\text { 条件 }\end{array}$ & 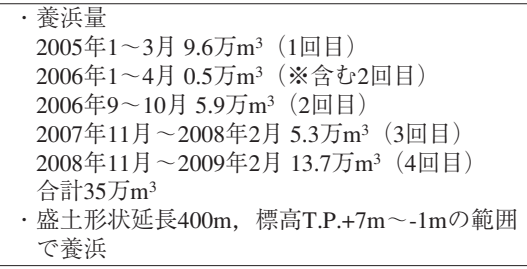 \\
\hline
\end{tabular}




\begin{tabular}{|c|c|}
\hline & $\begin{array}{l}\text { ·投入方法 ※再現は } 2 \text { 回に分けて投入 } \\
\text { 1) } 2008 \text { 年再現時 } \\
2005 \text { 年投入分 }(1 \sim 3 \text { 回まとめて盛土幅 } 80 \mathrm{~m}) \\
80 \times 400 \times 8=25 \text { 万 } \mathrm{m}^{3} \\
\text { 2） } 2009 \text { 年再現時 } \\
2008 \text { 年投入分 }(\text { 離岸堤 } 2 \text { 基同時設置後 }) \\
4 \text { 回目を残存している盛土に対して, 追加盛土 } \\
\text { 幅 } 30 \mathrm{~m} \\
\quad 30 \times 400 \times 8=10 \text { 万 } \mathrm{m}^{3}\end{array}$ \\
\hline 構造物条件 & $\begin{array}{l}\text { 1) 既設構造物 }(2005 \text { 年再現で考慮 }) \\
\text { 離岸堤 (6基) } K_{t}=0.4 \sim 0.6 \\
\text { 消波堤 (15基) } K_{t}=0.2 \sim 0.3 \\
\text { 導流堤 (2ヶ所 : 馬込川, 今切口) } K_{t}=0.0 \\
\text { 2) 新設離岸堤 (2009年再現で考慮) } \\
\text { 2007年11月着工 } 2008 \text { 年2月末完成 (2号離岸堤) } \\
\text { 2008年 } 11 \text { 月着工 2009年3月末完成 (1号離岸堤) } \\
\text { 新設離岸堤 (2基) } K_{t}=0.4\end{array}$ \\
\hline
\end{tabular}

質的（粒径）変化も起きた. 海浜の質的変化は, 細砂中 砂で構成されていた海岸に図-3に示すように粒径 $19 \mathrm{~mm}$ 以上の大礫を多く含む養浜材が大量に投入されたことに よる.図-4 は図-1に示す測線No.12 とNo.162における養 浜前後の底質の水深方向分布（静岡県, 2009）を示すが, 大きく前進した汀線付近で碟の含有率が著しく高まった ことがわかる.

石川ら（2010）は，2009年9月 15，16日，延長 400m の養浜区間を含む馬达川河口西側の $2.5 \mathrm{~km}$ 区間で前浜〜 砂丘の地形測量を行うとともに，堆積砂の分布状況を調 べた。この調査によれば，礫の移動に関し図-5の結果が 得られている。ここに大砂，中砂，細碟の区分は，粒径 $\mathrm{d}$ がそれぞれ $19<d<75 \mathrm{~mm}, 4.75<d<19 \mathrm{~mm}, 2<d<$ 4.75mmである。図-5によれば，大礫は養浜区間西端から 西へ $0.7 \mathrm{~km}$ まで到達したが，細礫中礫は約 2 倍の $1.6 \mathrm{~km}$ ま で広がりを示している。

\section{3. 計算方法}

磁を含む盛土養浜の変形予測では，砂〜礫に至る広い 粒径レンジを持った土砂が浜崖を形成しつつ投入点から 運び去られるという現象を再現する必要がある。このた
め本研究では熊田ら（2003）の粒径を考慮した等深線変 化モデルを用いて予測計算を行った。計算対象は，天竜 川河口から西 $30 \mathrm{~km}$ 地点までの海岸とした。最初に自然 状態にあり，水深 $2.5 \mathrm{~m}$ を境としてその陸側勾配が $1 / 40$, 沖側が $1 / 100$ であった 1962 年当時の海浜縦断形が沿岸方 向に一様に続くと考え，1962年当時の汀線への法線に対 して左斜めに $\theta_{w}=20^{\circ}$ の方向から波が入射するとし，沿岸 漂砂量が $3.0 \times 10^{5} \mathrm{~m}^{3} / \mathrm{yr}$ となるように漂砂量係数を同定し た。この条件で動的平衡海浜を造り出した。

予測計算では，このようにして求められた動的平衡海 浜に各種施設を配置し，天竜川からの土砂供給量が 0 と なったと仮定して 2005 年までの海浜変形予測を行った. この計算の後，4ケースの予測計算を行った。 ケース 1 で は2005年の養浜前の海浜形状を再現した。ケース 2 では 2008 年の離岸堤設置直前の海浜形状を，ケース 3 では 2009年の現況再現を，そしてケース4では現況のまま放 置して 10 年後の海浜形状を予測した。計算に用いた波浪 条件は，対象期間のエネルギー平均波 $\left(H_{0}=1.6 \mathrm{~m}, T=7 \mathrm{~s}\right)$ とし，またメッシュ間隔は $\Delta X=100 \mathrm{~m}, \Delta Z=1 \mathrm{~m}$ とした。 再現計算においては離岸堤の建設経緯を考慮し，また離 岸堤の透過率は 0.4 とした. 表-1には計算条件をまとめて 示す.

\section{4. 計算結果}

図-6 (a) は，馬込川河口付近と2基の離岸堤を含む $3 \mathrm{~km}$ 区間の初期形状（1962年）と2005年の等深線の計算結果， および2005年測定の汀線形状を示す。初期の平行等深線 は，左境界（天竜川河口方面）からの沿岸漂砂量の枯渇 と，馬込川導流堤による沿岸漂砂の阻止などの影響によ り導流堤の西側直近で大きく後退しているが，汀線変化 の予測結果は実測結果とよく対応している。図-6 (b) は 図-6 (a) に位置を示す $\mathrm{X}=5.9 \mathrm{~km}$ 断面の縦断形を示す．初 期粒径として $\mathrm{d}=0.25 \mathrm{~mm}$ の砂（平衡勾配 1/100）と, $\mathrm{d}=0.425 \mathrm{~mm}$ の砂（平衡勾配 $1 / 40 ）$ が均等に混ざった状態

調査: 2009 年 9 月 15 日

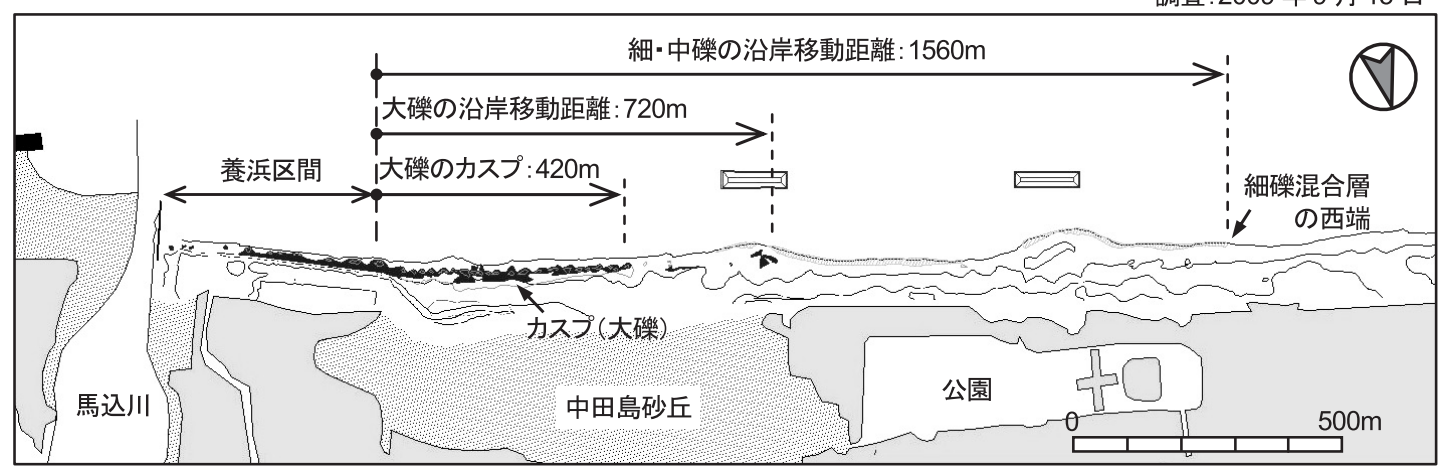

図-5 砂の分布状況と粒径別の移動距離（石川ら，2010） 
(a) 等深線形状

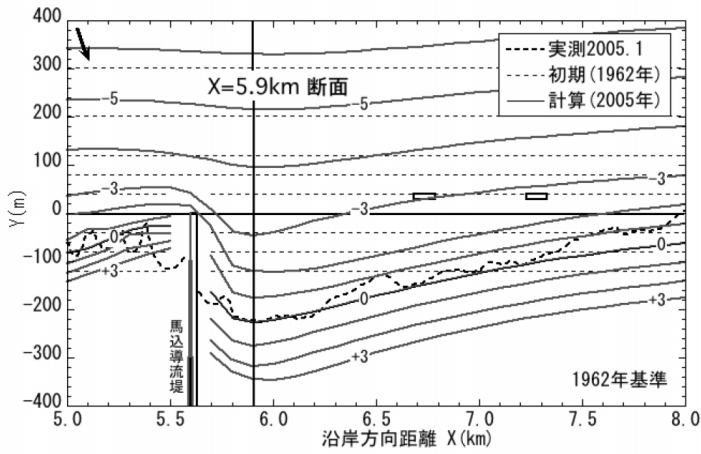

(b) 海浜縦断形 $(X=5.9 \mathrm{~km})$

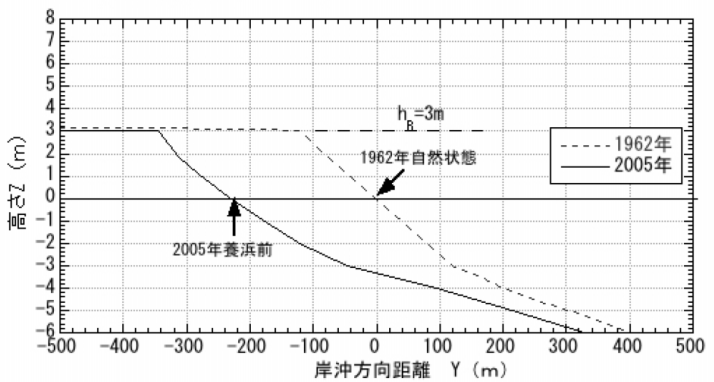

図-6 2005年の予測等深線変化と X $=5.9 \mathrm{~km}$ 断面における海浜 縦断形

を設定しているため, 初期縦断形は水深 $3 \mathrm{~m} よ り$ 岸側では $1 / 40$ 勾配，これより沖合では $1 / 100$ 勾配となる複合断面を 有する.この初期断面は, 馬达川河口導流堤の西側隣接 部での等深線の後退とともに縦断形が大きく後退したこ とが分かる．2008年の離岸是設置直前の地形変化予測で は, 盛土養浜が3回（養浜土砂量 $1.9 \times 10^{5} \mathrm{~m}^{3}$ ) 行われたこ とを考慮した。図-7 (a) は2005年（初期）と2008年の等 深線の予測結果を2008年の実測汀線形状とともに示す. これによれば，養浜区域から離れると一致度が低下する が，養浜区間近傍では実測・予測汀線はよく一致してい る. 図-7 (b) にはX=5.9km 断面における縦断形変化を示 すが, 盛土養浜によって形成された突出部では浜崖を形 成しつつ2008年まで汀線が $40 \mathrm{~m}$ 後退している。浜崖部分 から汀線に供給された土砂は沿岸漂砂により次々と運び 去られるため水面下での堆積はほとんど見られない.

2008 年地形条件のもとで 4 回目の養浜が行われた後の 2009年の同様な予測結果を図-8 (a)（b）に示す。図-8 (a) に示す予測等深線形状のうち汀線について計算と実測形 状を比較すると, 計算のほうが実測より侵食量がやや過 大な結果を与えているが, 離岸堤周辺での汀線の場所的 変化はうまく説明されている.また図-8（b）に示す $\mathrm{X}=5.9 \mathrm{~km}$ 断面における縦断形変化によれば，2008年まで に浜崖の形成を伴いつつ後退した汀線が養浜によって再 び前進したが，それも波の作用で侵食され，2009年9月 (a) 等深線形状

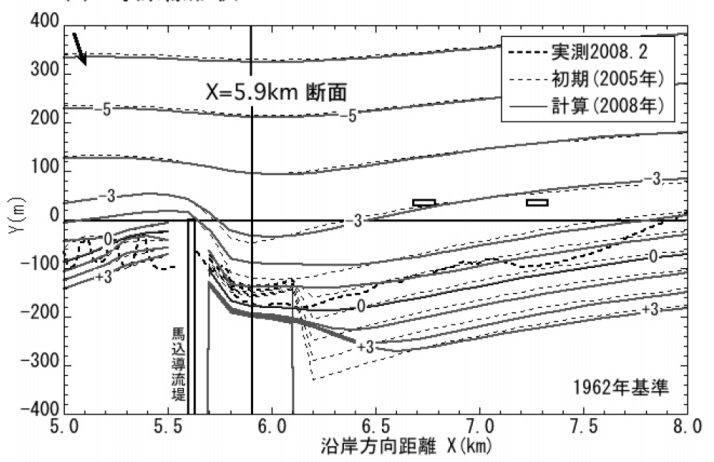

(b) 海浜綐断形 $(X=5.9 \mathrm{~km})$

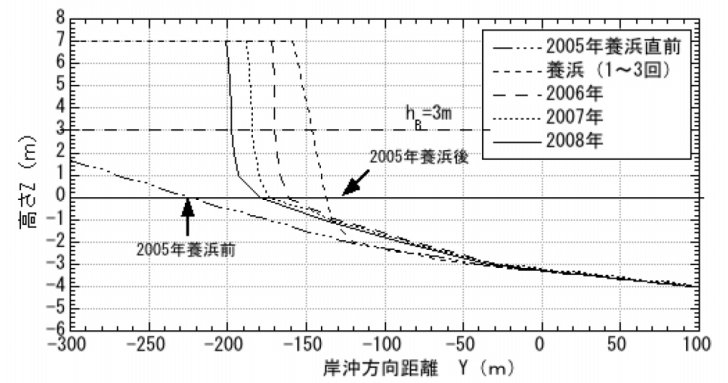

図-7 2008年の予測等深線変化と $X=5.9 \mathrm{~km}$ 断面における海浜 縦断形

(a) 等深線形状

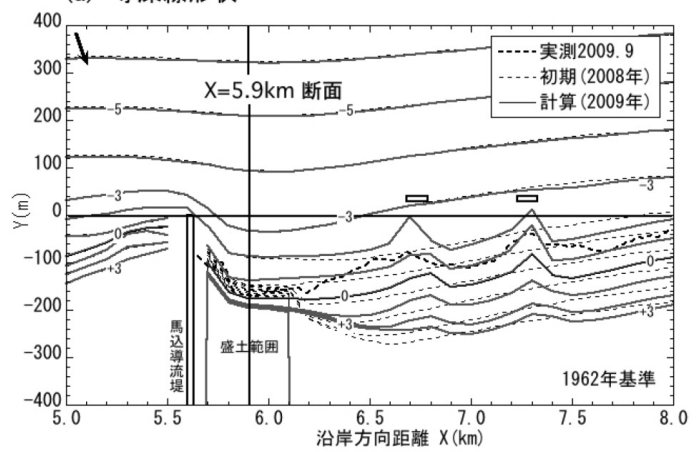

(b) 海浜縦断形 $(X=5.9 \mathrm{~km})$

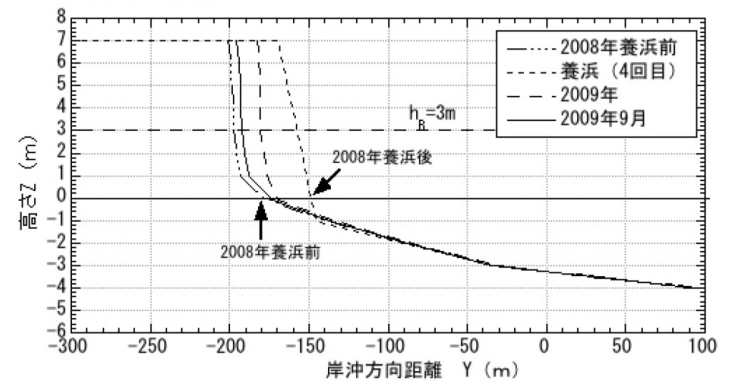

図-8 2009年の予測等深線変化と X=5.9km 断面における海浜 縦断形 
(a) $\mathrm{d}_{4}=9.5 \mathrm{~mm}, \quad \tan \beta=1 / 5$

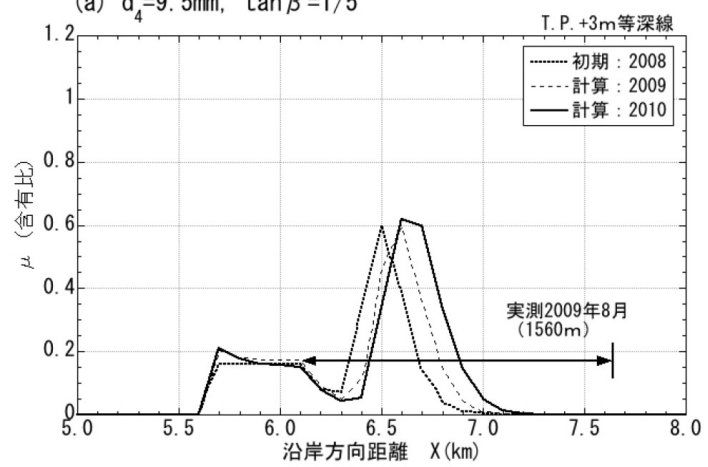

(b) $\mathrm{d}_{5}=26.5 \mathrm{~mm}, \quad \tan \beta=1 / 2$

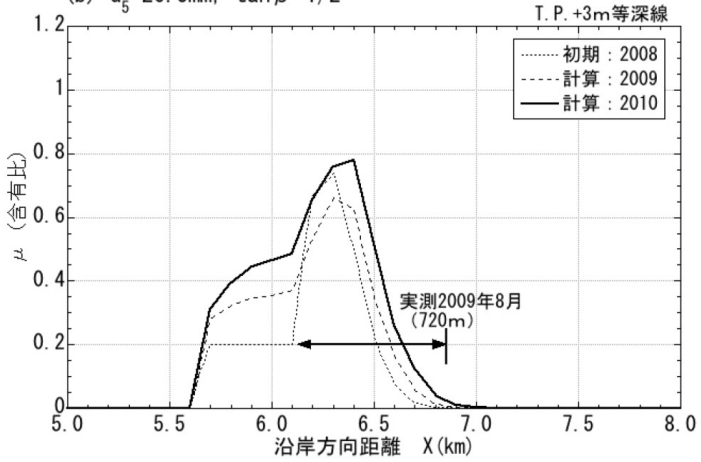

図-9 礫の移動距離の比較

の縦断形は2008年養浜直前の縦断形とほぼ等しくなるま で後退したことが見てとれる．投入土砂の粒径が大きい ため，盛土養浜区間から沖向き漂砂は起こらず，したが って沖合には砂礫の堆積域が形成されていない. 以上よ り，養浜土砂は西向き沿岸漂砂によって運ばれたことが 分かる.

一方，石川ら（2010）に詳細を示したように，礫は前 浜上に堆積しつつ次第に沿岸方向に運ばれた。その場合 粒径に応じて移動速度が異なるために，碟の沿岸方向の 拡散域は粒径に依存して異なり，小粒径ほど拡散域が広 いると考えられる。図-9は粒径レンジが $9.5 \leqq d<$ $26.5 \mathrm{~mm}$ で代表粒径が $\mathrm{d}=9.5 \mathrm{~mm}$ の嘫（d4）と，粒径レン ジが $26.5 \leqq d<75 \mathrm{~mm}$ で代表粒径が $\mathrm{d}=26.5 \mathrm{~mm}$ の砂（d5） について，標高 $3 \mathrm{~m}$ 位置（バーム上）で沿岸方向の広が り区域の予測結果を実測結果と比較したものである。図 には2009年 8 月に測定した $\mathrm{d} 4 ， \mathrm{~d} 5$ 相当の礫の広がり区域 の西端位置も示すが， $\mathrm{d} 4$ の広がり区域は過小評価である ものの，d5成分については実測值と予測值とはほぼ一致 している.

\section{5. まとめ}

本研究では浜松篠原海岸で行われた粗粒材養浜による
海浜変形の実態データを検証材料として，熊田ら（2003） の粒径を考慮した等深線変化モデルを用いて砂の移動状 況の再現計算を行った。計算結果によれば，繰り返し行 われた盛土養浜に伴って海浜縦断形は前進したが，養浜 後波の作用で浜崖を形成しつつ後退する状況について子 測と実測でかなりよい一致を示すとともに，26.5 $d<$ $75 \mathrm{~mm}$ で代表粒径が $\mathrm{d}=26.5 \mathrm{~mm}$ の礫（d5）の広がり区域の 予測結果もほぼ妥当な結果が得られた。これらより実用 的意味で本研究の方式が有効利用可能なことが分かっ た。一方，浜松篠原海岸での粗粒材を用いた盛土養浜で は，浜崖を形成しつつ養浜土砂が海岸へと供給されるも のの, 浜崖の後退とともに波の作用が起こりにくくなり, 結果として一定割合で下手側海浜へと砂礫を供給するこ とが難しいことも明らかとなった。そのためには浜崖の 後退とともに土砂を押し出す作業も必要になると考えら れる。その海岸において流れることが期待される沿岸漂 砂量に見合った土砂量をいかにスムーズに供給するかに ついて検討することが今後の課題である.

謝辞：本研究においては, 静岡県浜松土木事務所より空 中写真や粒径データなどの貴重な資料を提供していただ いた。ここに謝意を表します。また，本研究は文部科学 省科学技術・学術政策局の科学技術振興調整費による重 要課題解決型研究等の推進「先端技術を用いた動的土砂 管理と沿岸防災」の研究成果であることを付記し, 研究 の推進に預かった方々に感謝の意を表します.

\section{参 考 文 献}

石川仁憲 - 宇多高明 - 三波俊郎 (2010) : 粗粒材養浜時の海浜 の質的変化と砂の移動特性, 海洋開発論文集, 第 26 巻, pp.1077-1082.

宇多高明・石井 隆 - 内田光一.甲賀 肇 - 影山安秀 - 古池 鋼 - 石川仁憲 (2006): 遠州灘海岸における長期的海浜変 形予測と養浜の効果検討, 海岸工学論文集, 第 53 巻, pp.666-670.

宇多高明 - 吉添高兆 - 町井 靖 - 山本剛史 - 古池 鋼 - 芹沢 真澄・石川仁憲（2007）:粒径を考慮した等深線変化モデ ルによる細砂・粗砂養浜の効果検討, 海岸工学論文集, 第 54巻, pp. 641-645.

熊田貴之・小林昭男・宇多高明 - 芹沢真澄 (2003) : 沿岸·岸沖 漂砂による粒径分級を考慮した等深線変化モデル, 海岸工 学論文集, 第 50 巻, pp. 481-485.

酒井和也 - 小林昭男 - 宇多高明 - 芹沢真澄 - 熊田貴之 (2003): 波の遮蔽構造物を有する海岸における3 次元静的 安定海浜形状の簡易予測モデル, 海岸工学論文集, 第 50 巻, pp. 496-500.

静岡県 (2009): 第 12 回 遠州灘沿岸侵食対策検討委員会資料. 長島郁夫 - 岩崎伸昭 - 宇多高明 - 有村盾一 (2005): 遠州灘海 岸の天竜川河口以西の侵食実態, 海岸工学論文集, 第 52 巻, pp. 596-600. 